\title{
Dismantling whiteness: Silent yielding and the potentiality of political suicide
}

\author{
Vincent Jungkunz \\ Department of Political Science, Ohio University, Athens, Ohio, 45701, USA. \\ E-mail: jungkunz@ohio.edu
}

\begin{abstract}
This article attempts a re-configuration of silence, suicidal identity deconstruction and the politics of anti-racism. I will explore the potential of dismantling whiteness by way of a silence that involves the refusal to claim whiteness, a whiteness that, in effect, denies humanity to 'others'. Such silences are insubordinate, as they challenge the hegemony of a racialized polity, attempting to resist its privileges, as well as its destructive and restrictive consequences.

Contemporary Political Theory (2011) 10, 3-20. doi:10.1057/cpt.2009.44
\end{abstract}

Keywords: silence; democracy; resistance; racism; whiteness; silent yielding

Suicide is underrated as a political practice. Some identity formations are characterologically oppressive and discriminatory. By definition, these identities necessitate the existence of 'others' deemed inferior and thereby subjected to widespread and devastating subordination. Such socially constructed oppressive identities need killing off, extermination and destruction - a real doing of deconstructive violence. These identities cannot be reformed; they cannot be critiqued with any hope that from such critique will emerge a more benevolent and less oppressive set of subjects who have been so constituted. Such privileged identities, protected and positioned as they are within power, are not likely to be destroyed externally. These 'identities' can only be dismantled by those whose experiences and resources are so tightly linked to such identities that they, in turn, attribute to them their very being. In other words, what is needed, to get rid of such oppressive identities is, in a sense, to encourage the widespread suicide of privileged identity-infused selves. The potential of such suicides has nothing to do with a killing of the body itself. When a depressed human being attempts to leave this world entirely via terminating their very physicality, it speaks to a fundamental failure within the community in which such an act of desperation occurs. What I am encouraging is something much different, and actually quite promising. There are multiple 
identity existences that can be killed off by the self/subject, while leaving the body, and a different sort of mind and life, intact.

Silence, like suicide, is also underrated, at least in western contexts. In far too many instances, a silence/speech binary is embraced that leaves silence rendered meaningless and neglected. In political science generally, and political theory more specifically, silence has been analyzed with two seemingly dissimilar frameworks. The first approach tends to shun silence as a practice ripe for political analysis. Silence is treated as an absence, a 'pure' absence that signals no political activity, thought or behavior. Or, alternatively, silence within this tradition is treated as a form of tacit consent. This is an absence of a different sort. Silence among citizens is the sign of the absence of conflict regarding a given political position, policy or reality. The second broad approach to silence in the discipline treats silence as a political phenomenon that exists as a result of power relations between political agents or emanating from powerful structural influences. This tradition, quite important in feminist and critical race theories (hooks, 1989; MacKinnon, 1989; Minh-ha, 1990; Duncan, 2004), illuminates the ways in which people come to be silenced as a result of power dynamics. Although each of these postures toward silence differ in that one tends to ignore the role of silence in politics while the other sees silence as an important part of political contestation, they are both what Kennan Ferguson calls 'denigrated silence' (2003, pp. 50-54) as they share an emphasis upon the inactive, absent, quiescent quality of silence. Neither approach envisions the ways that silence can itself be an active part of political deliberation, debate and struggle. As a result, these approaches have left democratic theory somewhat under-developed. The problem is that a onedimensional focus upon the dangers of silence might severely limit and obscure the democratic potential of silence, not only in the sense that silences can be quite meaningful deployments of political messages, but also in the sense that silence can be an engagement in absence, and this very absence can actually be a democratic posture that helps shape the contours of life, political and otherwise.

Finally, an anti-whiteness politics has been quite underrated and undertheorized as well. We have yet to witness a thoroughgoing coming-together of anti-racism with anti-whiteness, thereby, some could argue, leaving racism as white supremacy firmly intact. Not only have there existed many dynamics that silence racial minorities regarding their experiences of racial oppression and contemporary forms of racism, there have also been powerful silences among white subjects regarding their whiteness as power and privilege. This article attempts a re-configuration of silence, suicidal identity deconstruction and the politics of anti-racism. I will explore the potential of dismantling whiteness by way of a silence that involves the refusal to claim whiteness, a whiteness that, in effect, denies humanity to 'others'. Such silences are insubordinate, as they 
challenge the hegemony of a racialized polity, attempting to resist its privileges, as well as its destructive and restrictive consequences. I consider how whiteness as privilege is supported and perpetuated by an epistemology of ignorance. This ignorance helps induce whites into a passive silence regarding tackling racial inequalities in the United States. I focus on racial dynamics in the United States because of the unique combination of historical slavery, constitutional attempts to alleviate racial discrimination, a long era of de jure discrimination, a seemingly (formally) successful civil rights movement and the intractability of contemporary racial inequality. An almost schizophrenic professed commitment to equality coexists with deeply embedded white privilege. I turn to storytelling as a method for addressing racial misunderstanding. Silent yielding is offered as a political practice among whites as a way to make discursive and reflective room for stories that can bring to light the continued prevalence of racism. Insubordinate silences, as protest and refusal, are put forth as viable ways for whites in particular to work to self-negate, therefore opening up democratic possibilities that frankly cannot exist in racialized polities. Ultimately, this article is about the silences that tend to perpetuate privilege and the potential silences that might work to reduce such privilege, thereby working to chip away at whiteness as power and privilege and racism as white supremacy. I envision the widespread suicide of white subjectivities.

\section{Some Notes on Silence}

While challenging more dichotomous approaches to silence, this article does not necessarily view such dichotomies as useless for political purposes. KingKok Cheung, Adam Jaworski and Ferguson, among others, speak to how the dominant paradigm in western societies toward speech and silence tends to exclude silence from the realm of positive behavior. In fact, while speech is somewhat glorified as empowering and even sometimes dangerous, silence is treated as signaling mere absence. Cheung states, 'Silence, by contrast (to speech), has often been perceived negatively as absence, or as 'an outof-awareness phenomenon - the ground against which the figure of talk is perceived' (1993, p. 1). One of the flaws of this speech/silence binary is the assumption that silence as absence is always non-participatory, or inactive. In contrast, I will argue below that absence itself can be a form of insubordination, a refusal that can be quite powerful. Silent absence can be a resistance of the discursive structures or configurations that tend to manage the distribution of meanings that direct our lives.

While silence as an absence that is political has been a neglected form of silence's potential as insubordination, it is the case that silence as signaling 
meaninglessness has been a real error under more traditional approaches to speech emanating from western contexts. The view that silence does not convey meaning misses a major facet of silence in social, educational and political contexts. Muriel Saville-Troike notes that, 'Silence may be used to question, promise, deny, warn, threaten, insult, request, or command, as well as to carry out various kinds of ritual interaction' (1985, p. 6). Jaworski provides an example involving a neighbor who asks him how much money she owes for a favor he completed for her, stating, 'I was genuinely appalled at the question so I did not say anything and just looked peeved at the woman. After a moment, she said, slightly embarrassed, "Do you want me to jump out of the window?", (1993, p. 3). He then continues, 'I did not reply verbally to her question about the money, but she knew that I was offended by her inquiry, and she also realized that I was not going to accept any form of payment for the favor' (1993, p. 3). Cheung (1993) notes that silences employed in literature convey a series of meanings to the audience. She illuminates three such silences rhetorical, provocative and attentive - all of which are 'articulate', presenting hidden tales, spurring creativity and calling attention to the complexity of life. Silence, whether in everyday conversations between neighbors or within literary settings meant to tell a powerful story, conveys a variety of meanings, and it is this meaningfulness that can be used politically as a means of resistance and protest.

In addition to silence being deployed in ways that convey particular and substantive meanings, silence is also a functional part of discourse that, if used in untimely ways, can provide a means of resistance. Much of the way we interact with one another involves a series of artificial standards, orders and tempos. Bernard Dauenhauer discusses 'intervening silence' as 'that occurrence or sequence of occurrences of silence which punctuates both the words and phrases of a spoken sentence and the string of sentences which fit together in discourse' (1980, p. 6). He notes that, without intervening silence, the words, phrases and sentences that we use to communicate would emerge as gibberish. For Dauenhauer, these silences are a vital component to functioning discourse, helping us make sense of and to one another as we proceed. Much of this interaction relies upon conventional standards of timing. Because of the ways interlocutors come to accept and depend upon what become standard or normal ways that time is woven throughout a given communicative interaction, a change in these tendencies and practices can become a form of resistance and a way to take some measure of control over these ideational exchanges. Illuminating the importance of timeliness and untimeliness when being silent becomes a valuable tool in political contestation and participation. Dauenhauer notes, 'Thus at least part of the sense of intervening silence seems to be that it is one of the ways in which an utterance or a sequence of sound phrases can be stamped as "peculiarly mine", "anyone's", "yours and mine", 
etc' $(1980$, p. 8). This is a participatory facet of communicative interactions - the role of untimely silence in influencing the meanings that flow from such interactions. Untimely silences can certainly be insubordinate as they interrupt the flows of discursive structures, and attempt to wrestle back some measure of participation in the various ways in which we come to create meaning.

\section{Insubordinate Silences and Resistance}

Silence-as-absence-as-political, silence as conveying political messages and untimely silences, working alone or in concert, inform three kinds of insubordinate silence available for political contestation: silence for voice, silence as protest and silence as refusal. Silence for voice is the deployment of silence in order to draw attention to the ways in which an individual or group is or has been silenced. Silence as protest is not necessarily a call for the direct and immediate establishment of voice. Instead, it is a silence that calls attention to a grievous example of speech or perceived injustice. Finally, silence as refusal is a silence meant to turn away from a given discursive structure altogether. This form of insubordinate silence recognizes the ways in which discourses can act as prisons; and, that there may be times when it is beneficial to refuse being hailed into a given discourse altogether.

\section{Silence for voice}

Silence for voice is about using insubordinate silence in order to help solve the predicaments associated with being silenced. For the most part, those who advocate voice have focused exclusively upon voice as the vehicle for liberation. And, as a correlate, they have directly challenged the prevalence of silence itself. Insubordinate silence for voice, instead, seeks to use silence as a form of empowerment. Instead of exclusively meeting voices that silence with vocal resistance, a careful and tactical deployment of silence might help draw attention to the reality of being silenced and work as a form of discourse that conveys the position that the silencing itself is unacceptable. At first glance, it might seem counterintuitive and counterproductive to envision silence as a way to alleviate the problems of silence - how can silence break silence? Yet, it is important to note that many times it is not a totalizing silence that is enforced by those in power, but a series of silences regarding specific areas of life, and this silence occurs alongside things that are said that do not directly challenge the status quo. So, while one certainly does not want to engage in a silence that only perpetuates one's silence in a given area, one can tactically deploy silence in areas in which one is depended on for voice. 


\section{Silence as protest}

Silence as protest is not necessarily a direct response to the phenomenon of being dominated via being silenced. Instead, it is about challenging the ways in which speech itself can be very damaging to individuals and groups. Lisa Block de Behar notes that silent protest can entail 'a rebellion against the abuse of words' (1995, p. 6). Cheung states, 'Certainly, language can liberate and heal, but it can also distort and hurt; and while silence may smother and obliterate, it can also minister, soothe, and communicate' (1994, p. 114). Silence as protest can also be used to resist and call attention to unjust conditions and behaviors. Like silence for voice, silence as protest relies upon the ways in which silence itself can convey important messages. Jaworski's silent response to his neighbor signified his protestation against her socially awkward offer of money for services performed. Silence as protest is not about calling for voice per se, but instead about calling attention to dysfunctional and destructive voices and discursive realities and injustices.

\section{Silence as refusal}

Another way that silence can be used as a form of insubordination involves silence as an intentional absence or self-exclusion from a given terrain of political contestation and constitution. Silence as a refusal to speak and as a self-imposed absence on certain matters altogether can be a refusal to enter discourse, a refusal of the political as discursive contestation; or it can involve a refusal of a specific discursive construct in order to make ideational space for, or to conserve, another. Ferguson states, 'The very existence of silence thereby becomes a form of resistance, of non-participation in these practices of community building, identity formation and norm setting. Silence, in other words, betokens a rejection of these practices of power' (2003, p. 54). Silence as refusal and resistance is related to the concept of interpellation. Donna Haraway states, 'interpellation occurs when a subject, constituted in the very act, recognizes or misrecognizes itself in the address of a discourse. Althusser used the example of the policeman calling out, "Hey, you!" If I turned my head, I am a subject in that discourse of law and order: and so I am subject to a powerful formation' (1997, p. 50). It might be that the most fundamental way in which silence can be deployed politically is to, in an untimely manner, refuse interpellation. After the 'Hey, you!' there is the issue of 'if'. 'If' the head is turned, one becomes subject to a given discursive construct. The moment one is called is an opportunity, an opportunity to engage whatever discursive construct will surround you the moment you answer, but also the opportunity to not answer, to refuse the given discursive construct - an opportunity for 
desubjugation. It can be an untimely absence that reconfigures the terrains of the political landscape.

A political event and effort that exemplifies these forms of insubordinate silence is the annual Day of Silence. The Day of Silence is an effort by the Gay, Lesbian, and Straight Education Network (GLSEN) to expose the ways in which members of this community are silenced everyday. Participants of this protest, typically high school and college students, take a vow of silence for an entire day. The objective of the Day of Silence is empowerment through voice the other 364 days of the year. Individuals deploy silence in settings in which they are usually expected to speak, thereby establishing gaps in the discursive flow, significant and substantive gaps that impact the quality and quantity of things said and ideas conveyed, or things not said and ideas not conveyed. Under a section entitled 'Why Silence?' the organization states,

The Day of Silence is a way of turning silence on its head, of reclaiming silence as a tool. The Day of Silence institutes a visible silence, a silence during which participants protest anti-LGBT discrimination and abuse. Such an effort also allows us to reflect upon how powerful silencing can be, to focus on how we can make our own voices stronger and to begin to stop silencing ourselves. (GLSEN, 2006)

This is an organized and communal use of silence. It is both a form of protest and a vehicle for voice. It is to draw publicity, educate and empower. It also works to symbolize a refusal of a discursive status quo that involves a configuration of utterances that need rejecting in order to open more democratic possibilities for LGBT subjects.

\section{White Privilege and Silence}

Critical race theorists have invested much effort highlighting that white privilege is one of the most prominent and pervasive manifestations of contemporary racism. White privilege involves the many resources that white subjects accrue simply by inhabiting the social terrain as white. These subjects need not engage, materially or ideologically, in blatant forms of racist thought and behavior; yet, they still find themselves the beneficiaries of their whiteness. A quite simple, but instructive, example of white privilege emerges from my epistemic authority in the classroom. When I walk into the classroom as a white professor, my whiteness brings with it a series of assumed characteristics (such as intelligence, academic relevance, legitimate authority and so on) among the students that sit in front of me. These assumptions act as resources not available to my non-white colleagues. One aspect of white privilege, maybe 
the most important aspect of its continued existence, is its lack of visibility for those who have it. Ian Haney Lopez states, 'Transparency, the tendency of Whites to remain blind to the racialized aspects of that identity, is omnipresent' (1996, p. 157). Whites are not introduced to race and racism via the lenses of white privilege. Peggy McIntosh points out that, 'As a white person, I realized I had been taught about racism as something which puts others at a disadvantage, but had been taught not to see one of its corollary aspects, white privilege, which puts me at an advantage' (2004, p. 104). Teachers and educators, for instance, should assume that white students are fairly ignorant of the ways in which their lives are structured through racial privilege. Lopez illuminates how this transparency further enlarges and perpetuates privilege itself, stating, 'Never forced to experience or reflect upon the petty indignities and intentional slights of racism, most Whites are free to act in the world with energies undiminished by the anger and self-doubt engendered among racism's victims. A result of privilege, transparency also confers privilege' (1996, p. 159). Students and professors alike engage a back and forth conferring of privileges that are treated as non-racialized and non-existent as privileges. My privileges as a white professor are not only under the radar of critique, they appear as non-entities, thereby not subjected to the radar of racist tactics and phenomena.

Charles Mills (1997) points to an epistemology of ignorance that perpetuates global racial inequality. Building upon critiques of contractualism that seek to unmask the ways different groups have been subordinated within, and excluded from, theoretically social contract regimes (Carole Pateman's The Sexual Contract being exemplar), Mills illuminates the racial dynamics underlying white polities. The 'Racial Contract', a series of formal and informal agreements that have structured contemporary settings through white supremacy, relies upon the invisibility of white privilege; it constructs a world in which whites come to see themselves as deserving of their status based upon both explicit and implicit notions of racial superiority. A major means through which this comes to pass is the ignorance surrounding the racial polities we find ourselves inhabiting. For whites to participate in a contract that confers personhood only upon some in a context that professes that all people are created equal, human beings must be constructed as other than fully human. Treating people of color as inherently inferior means their disadvantage will likely not be a moral dilemma in the white mind. Mills states,

Thus in effect, on matters related to race, the Racial Contract prescribes for its signatories an inverted epistemology, an epistemology of ignorance, a particular pattern of localized and global cognitive dysfunctions (which are psychologically and socially functional), producing the ironic outcome that whites will in general be unable to understand the world they themselves have made. (1997, p. 18) 
This epistemology, which teaches, socializes and infuses race in ways that betray reality, is fundamentally important in maintaining and perpetuating white privilege. White friendships, relationships, marriages, love, professional networks, television programs, movies, corporate structures, policies, attitudes, opinions are not deemed white or privileged. Instead, they are the social norms to be aspired to, even if they are only accessible to some. As such, they receive little, if any, 'debate', interrogation, questioning, critiquing or analysis as racial constructs, and, lots of silence.

A paradox surrounds whiteness, talkativeness, silence and ignorance. For many whites, there is a significant amount of speech engaged regarding matters of race. Derrick Bell argues that whites are given a heightened standing when discussing and 'debating' issues surrounding racism, thereby multiplying the amount of white speech surrounding these discourses (1992, pp. 113-114). However, in spite of white speech on issues of race, there is an enormous amount of silence surrounding issues of whiteness as property and privilege. Mills' The Racial Contract speaks to the vast historical and contemporary silences regarding white supremacy as an organizing feature of racialized polities. These are silences infused with ignorance, and, it is this silenceignorance combination that storytelling and silent yielding may help break.

\section{Storytelling and Silent Yielding}

Critical race theorists illuminate the viability and effectiveness of stories for understanding, speaking and teaching about 'race' and racism. Delgado and Stefancic point out that, 'Critical race theorists have built on everyday experiences with perspective, viewpoint, and the power of stories and persuasion to come to a better understanding of how Americans see race' (2001, p. 38). Stories highlight the trials, injustices and microaggressions that accompany being racially discriminated against in the United States. Such stories can give whites insight into life outside their racially parochial experiences. Delgado and Stefancic state, 'One premise of the new legal storytellers is that members of this country's dominant racial group cannot easily grasp what it is like to be nonwhite' (2001, p. 39). Stories can be an effective means of breaking down white resistance to understanding whiteness as privilege. In doing so, these stories can break the silence over white privilege while simultaneously leading to more white silence over dubious accounts of reverse discrimination. Such storytelling relies upon discursive opportunity, opportunity that can be produced through the practice of silent yielding.

Storytelling helps illuminate the important ways that speech and silence, working together, can effectively initiate important political and social change. Sometimes, silence is used to disrupt speech that monopolizes; sometimes 
silence is used to protest injustice. Other times silence is deployed to break up relationships and unitary discourses. Yet, paradoxically, some of these same silences simultaneously help unify disparate political groups, as they interact with utterances. Silent yielding is just such a silence. When practiced by whites, it can do several things simultaneously. First, it becomes a conscious protest against racism. Second, it acts as a refusal and disengagement from whiteness as privilege and power. Third, it opens up discursive space for the telling of stories and thoughts that can fundamentally transform citizens who listen. This can be just the sort of transformation sought after by anti-racists and deliberative democrats alike. Finally, it allows for a unity that challenges divisions that preclude more authentic attempts at democracy.

To properly tell a story, the context must be made ripe for telling and reception. This must involve a yielding, a willing silence that paves the way for talking and listening. Dauenhauer notes, related to bridging the gap between the 'us' and the 'other', that, 'This other reaches the agent only through the agent's yielding. Thus there is the awe-filled realization that he who engages in active performances has a responsibility for letting this other appear. The silence of the agent acknowledges this awesome responsibility' (1980, p. 25). Here, an insubordinate silence can also be a yielding and responsible and mending silence, a democratic silence that encourages participation from historically oppressed voices, and participation from historically inept listeners. Dauenhauer makes several important points that can make significant contributions to dialogue surrounding race. Although silent yielding becomes recognition that there is power beyond one's control, being situated within a position of discursive privilege can preclude such recognition. In fact, being one who, intentionally or not, monopolizes discussions entails a negation of the other.

In negating the other, one also negates the valuable epistemological resources offered by the other. Wendy Brown points out that, regarding such one-way communication, "very little of it bears the character of either social connection or reflection. Most of this speech confesses, pronounces, or declares, and practically none of it is aimed at developing community with others or with working through experience or transforming understanding' (2005, p. 96). Owing to the significance of the epistemology of ignorance for issues of race and racism, its support of the racial contract, the importance of gaining insight through community with others and reflective engagement cannot be overstated. Yet, a social setting that urges an almost incessant pronouncement of one's every thought, with the idea that each opinion is as valid as the next, can preclude transformative understanding. Brown continues, 'This subject who is so radically in need of external resources for understanding its context and production in our time is deprived of those very resources through pronunciative speaking' $(2005$, p. 96$)$. The white subject stands with 
the male subject as possibly in most need of external resources for understanding. Both subjects seem infused with a lack of racial and gender self-consciousness that external resources become vital if either is going to attempt dismantling of privilege. Speech itself can do real violence to both others and to the potentiality of alternative ways of living life together (Cover, 1995). Silent yielding becomes a practice of political and epistemological humility; one that helps open space for fruitful interactions previously precluded by one-way communication and silencing.

Silent yielding can be a practice for unity. It is a silence that seeks to 'meet that which lies beyond' (Dauenhauer, 1980, p. 25). Under racial polities, that which lies beyond is the racialized other. The promise of practicing silent yielding is that it can bridge the beyond, and provide the opportunity for connection. It is important to note that such a connection depends so much upon the one from whom yielding must emerge. In others words, the other is reached only through the yielding of the yielder. This is an 'awesome responsibility', one that, when engaged, unmasks fundamental relationships. Again, such insight can be crucial for facing the racial contract. The dysfunctional character of this contract is such that reaching out through silent yielding is unlikely. The 'other', according to the terms of the contract, is so inherently inferior to the white subject that reaching out would not only be futile, it would be inappropriate and dangerous. Under the racial contract, it becomes difficult for a feeling of responsibility for reaching out to emerge; this makes such yielding that much more important, provocative and potentially influential. Dauenhauer continues, 'deep silence binds him who performs it to that which is other and not inferior to him, however this other is interpreted' (1980, p. 25). This silence challenges racism and white privilege - this is the insubordinate part, and it democratically encourages a participatory spirit that casts its net much wider. In relation to the discourse of white supremacy, those who engage deep silence regarding the 'other' resist the terms of the racial contract. In doing so, they more authentically adopt a posture of equality. Rejecting the idea of racial inferiority becomes a vehicle for a more inclusive democracy.

Although insubordinate silence can be about disrupting a unity, it can also be about contributing to an untimely unity, or binding of things, ideas and people together so that we might be a more democratic community. Ferguson illuminates the ways that silence can 'form the artistic and intellectual basis for the recognition and constitution of communal identity' (2003, p. 62). It is a white silence that protests racism, calls attention to silencing, and ultimately works to shun and refuse the entire truth regime surrounding whiteness itself. This is crucial regarding racial politics and the power of whiteness. Silence might be the only viable communicative vehicle for an authentic anti-racist politics among whites. Not only does yielding create space for stories that push 
back against ignorance, white yielding can be a way to give one's self up for a more democratic whole. Silent yielding becomes a way to disengage more deeply a subject position that necessarily entails the subordination of others. Critical race theory, linked with an understanding of silence that abhors silencing but embraces fruitful reticence, can illuminate how educators and citizens alike can deploy an intertwined silence and storytelling that can reconfigure a racial polity, a sexed polity, a classed polity. As citizens and educators, we can learn and teach the political importance of yielding. Again, it seems that most of our contemporary effort goes into trying to speak, insisting on our way and being present upon a path that we desire - not a yielding, not a silence. Some silences are meant to engage others in relationality, whereas others are meant to be solitary practices. Silent yielding is a silence that is both self-disregarding and other-regarding. It is a silence meant to pave the way for another's voice. The act itself, the silence, is rich with meaning and transformation. And, the engagement that follows the practice of yielding can be a fruitful exchange that also transforms both the silence and the speech. Paradoxically, it is an engagement in disengagement (suicide) that leads to a more thoroughgoing democratic engagement and polity.

\section{Refusing Whiteness: Dismantlement through Suicide}

There are many ways in which voices matter. Talking matters for relationality. Talking matters for norm construction. Talking matters for participation in both. Talking also comes to matter as a major part of making a self. In one sense, silence as refusal is a strategy or practice that uses disengagement (most times temporarily) to improve a relationship or improve a world. It is a manipulation of the configuration of speech and silence within discourse in order to achieve a political end. It is because there are situations in which one's voice matters that such silences can be effective. Of course, silence can be overindulged and lose its potential to make a difference. In other words, one who uses silence too often could render one's silence illegitimate and ignored. Yet, used well, silence as refusal can help subjects negotiate power in everyday life. Beyond this, there are some silent refusals that might not really matter, at least not in the sense that they will directly affect other people, nor the political topography we inhabit. Yet, such silence does matter in the sense that it refuses to be a part of a given self-constitution. Engaging in such refusal does not necessarily entail a conceit on the part of the quiet one. Instead of the conceit that one's voice is so important that going silent will render one that much more powerful, some silent refusals are much more personal practices - working on oneself more than upon others, relationships or the world itself. And, beyond that, some are simply acts of self-denial - forms of purposive self-annihilation. 
Such silences entail a more thoroughgoing effort at disengagement. They might ultimately entail a sort of political suicide. What I have in mind is not the presence of words or actions that lead one out of a given engagement in politics. Instead, a deep silence and absence may be an option for those who wish to end a certain kind of political life, including the varied identities of contemporary politics. This sort of self-annihilation is certainly a controversial idea; it is tricky, maybe elusive, and potentially dangerous. However, maybe we should not let such difficulties deter us from examining its potential. Brown draws upon the metaphor of drowning in a pond to think through the implications and promises of using silence as a means of refusing compulsory discursivity. She states, "perhaps there are dead or deadening (antilife) things that must be allowed residence in a pond of silence rather than surfaced into discourse if life is to be lived without being claimed by their weight' (2005, p. 93). There are areas of our selves that we might desire to either keep submerged or commence to submerge. Silence might allow us to be discriminating regarding what parts of our lives we put into discourse. Yet, there is a more comprehensive practice of drowning in silence that seeks to submerge a given being; a being that emerges through a given identity. This might require us to think beyond life and death as purely dichotomous. This also can encourage us to think of the ways in which we, and the things we do and say, have multiple lives and multiple deaths. In doing so, we can revisit whether it is always a loss to allow certain selves we become to drown.

In relinquishing to death some of the lives we live, we may help create and/or perpetuate space for the constitution of other lives, lives for ourselves, and others. This might entail a strong sense of resistance in relation to contemporary hails that offer liberation through talking about what causes us pain. Such confessional practices can certainly help subjects deal with injury; yet, they might also place subjects into a unitary discourse that both regulates pain and recovery, but also excludes those who, for whatever reason, do not come to matter through voicing trauma. Brown continues, 'If to speak repeatedly of a trauma (which, by definition, carries wordless and even unintelligible content) is a mode of encoding it as identity, it may be the case that drowned things must be consigned to live in a pond of silence in order to make a world - a future - in parameters not fully given by the trauma' (2005, p. 94). Coming into a new existence, maybe even one that seems promising and liberating, through a trauma narrative might ultimately preclude exploration of ways of being less traumatizing and less confining. In a large way, this is about potential and possibility; there are no guarantees. Nevertheless, there are no guarantees that talking about one's pain will lead to the promise of weight being lifted and lives being transformed from shame to pride. Brown states, 'When all such experiences are put into discourse - when sexual, emotional, reproductive, and artistic lives are all exhaustively chronicled and thereby 
subjected to normativizing discourses - might this imperil the experiences of autonomy, creativity, privacy, and bodily integrity so long denied those whose subjugation included, inter alia, sexual violation or other deprivations of privacy?' (2005, p. 95). Silence provides an alternative, an alternative that does not have to be accompanied by feelings of guilt and shame for not talking.

If we can embrace silence as one way, among many others, to negotiate the meaning surrounding how we become together, it ceases to only be the symptom of a deeper sense of self-hate or the proof of being subjected to repressive silencing. How comforting it might be for those who suffer a variety of violations to their persons to know that allowing whole identities to stay submerged in a pond of silence does not mark them as cowardly? In telling and reactivating subordination, and attaching our self to an identity infused with suffering, we come to pay closer attention to our self. We look for signs that our feelings and behaviors are related to our suffering. We wonder if we are forever broken, wonder if we will gain acceptance and affirmation as we are this injured self. The point is not to belittle the experience of transcendence that some might accomplish in talking about suffering. The point is that, owing to a saturation of so much of our contemporary approaches to subordination by identity politics that seem wedded to injured selves, it might be wise to reconsider. And, this may allow us to ask different questions as we confront our past subordination and our future selves. What self or selves might we want to kill or extract from discursive life? What selves might we want to subject to a pre-emptive suicide?

In addition to considering whether those in historical positions of subordination should use silence to negotiate identity (de)construction, silent refusal that disengages a self can be a vital way to address privileged identities. Many of us exist along axes of identities. Some of the selves through which one might exist are pervasively imbued with realities of subordination. Yet, the same person can also exist within identity categories that include dominant positionality. Therefore, even those who suffer under discrimination and oppression in one aspect of their being might be able to wield power over others in another. Silence to dismantle such privileged status can be deployed by those whose identities intersect in ways that leave them highly privileged and among those who are only partially privileged. The goal is to use silent refusal as a way to undermine one's own privileged identities.

Regarding race, while white subjects can and do experience identity-based subordination in areas such as class and sex, as whites they are raced with privilege. It is as subjects of white privilege that all whites can use silence as refusal. As whites come to understand and perceive their racial privilege, there are at least two avenues of silence available as they navigate racial politics and identities; both avenues entail negation and death. They can be silent regarding their white privilege, thereby working to perpetuate the negation of 
under-privileged speakers and their identities. Or, they can begin a long engagement in silences that tend to self-negate. Block de Behar states, 'Silence is often an efficient instrument of obliteration, and one that leaves no traces' (1995, p. 9). The obliteration she is referring to is one in which those in positions of domination can engage a 'tricky' 'acknowledgment' when 'someone knows, yet he pretends he does not' (1995, p. 9). Whites who know, yet pretend they do not, are tacitly consenting to the racial contract, and they become directly responsible for white supremacy; this may entail silence, but it is not silent yielding. As an alternative, whites could engage in the obliteration of their whiteness, and open up ways of 'being' foreclosed by racial political societies.

Ultimately, a series of difficult choices await whites as they attempt to alleviate the oppressions that accompany a racial political and social context. Lopez points out, 'Whites' assistance in this endeavor is particularly crucial, because they exercise the great bulk of the tremendous power necessary to construct and maintain Whiteness' (1996, p. 188). In a sense, what is called for is a political, economic and social suicide regarding whiteness. Yielding in silence could be one appropriate avenue for challenging whiteness as voice and privilege and political speech. Lopez discusses the verbal denigration needed for the perpetuation of whiteness, stating, 'Whiteness demands that all Whites denigrate, at least passively, those constructed as non-White. It is only through this iterated denigration, this constant reinforcement by Whites of the lines between "us" and "them", that the boundaries of Whiteness can be maintained' (1996, pp. 189-190). The iterated denigration is certainly ripe for insubordinate silence. The Racial Contract depends not only upon ignorance, but also upon repeated speech that upholds discursive constructs that, furthermore, divide personhood from subpersonhood. These choices to dismantle whiteness, and the silences that can help lead the way to a society without whiteness, involve interrupting these iterations, stopping discursive flows, big and small. For instance, as one learns about racism and privilege, understanding that racism exists in multiple layers and forms, one can begin deploying silence to substitute for things such as soft and hard core racist speech, a monopolizing conversational style on race issues, and an out-of-focus consciousness that doesn't make room for self-conscious racial reflection. For whites, a lack of racial self-consciousness is an enormous barrier to overcoming racism and white privilege, and, one way to avoid self-consciousness is to talk incessantly, and to never listen to criticism.

A deep silence can accompany the choices we make as 'Whites', choices away from our white attachments. We can refuse the hail of whiteness by engaging absences - we can be absent at contexts that call us to perpetuate all-white realities. Derrick Bell points out how some discursive regimes are geared toward maintaining a white status quo in academia (1992, pp. 134-146). 
Visions of 'qualifications' can significantly preclude the inclusion of so-called persons of color from a variety of academic positions, including standards of scholarship oriented around more 'mainstream' conceptions of knowing and understanding. As noted above, some Critical Race theorists employ narrative and storytelling to illuminate issues of race; yet, these methods, under more traditional approaches, might be deemed 'soft' or non-scientific. The exclusion of such epistemic vehicles can then exclude their practitioners from academic jobs that continue to require too narrowly constructed visions of knowledge. To refuse such arrangements we can start by engaging silence - we can stop talking so much about one set of requirements, opening space for dialogue about other approaches, thereby shifting focus and potentially challenging those who walk away from job searches posturing frustration regarding what they perceive as an applicant pool lacking diversity. This is really a silent yielding that can adjust both our field of vision regarding something like a job search and the communities we construct throughout these processes and choices.

To reiterate, part of what privilege has involved in garrulous contemporary settings has been a monopoly over speaking. We have witnessed this surrounding sex, sexuality, race, class and gender. Masculine, white, 'heterosexual', wealthy men are privileged speakers. So, to engage insubordinate silence along any of these components of intersectionality is to engage several transformative contestations and participations. First, silence can demonstrate a protest against racism. Such protests can entail: silence instead of an encouraging laughter as a response to a co-worker's racially offensive joke, or an organized silent protest involving duct tape over one's mouth to call attention to oppressive quiescence. These silences can cut off the air (speaking) that gives life (via racist stereotyping) to white supremacy. Block de Behar notes, "that only silence can offer a means of avoiding the automatism of language' (1995, p. 4). Second, silence can act as a democratic yielding. This yielding is insubordinate as it challenges norms that try to dictate who should and should not speak - so, to remain silent as a way to allow the 'other' to speak is inherently resistant to a whiteness-speech configuration of power. This is a silence for empowerment and transformation. Finally, silence as a refusal can seek to end one political existence - whiteness - only to open up the possibility of an alternative to a racialized polity for the future. This silence as refusal can involve the following: not claiming a race on the census questionnaire, remaining silent when someone asks for racial identification over the phone or upon a personal ad and not engaging an entire array of racially offensive names, topics, movies, songs, discussions and so on. At an even deeper level, this silence can be an active refusal of aspects, characteristics white personality traits if you will - that slowly but importantly begin to kill off one's whiteness. For instance, the urge to speak up and out can be refused; the 
exuding of confidence can be refused; and even the lack of racial selfconsciousness can be refused.

\section{Conclusion}

This refusal of whiteness is complicated and multifaceted. Lopez breaks the dismantling process down into three facets. He states,

First, Whites must overcome the omnipresent effects of transparency and of naturalization of race in order to recognize the many racial aspects of their identity, paying particular attention to the daily acts that draw upon and in turn confirm their Whiteness. Second, they must recognize and accept the personal and social consequences of breaking out of a White identity. Third, they must embark on a daily process of choosing against Whiteness. (1996, p. 193)

The first component of dismantling is aided by silent reflection, which, again, is insubordinate in relation to the Racial Contract itself. Yielding in silence becomes a means for recognizing our interdependence upon one another, and a means for understanding our responsibility to be attentive to one another. This helps our attempt to accept personal and social responsibilities for dismantling whiteness, which can be an impetus for embarking against our white selves. In fact, the second step for dismantling whiteness is reflected in Dauenhauer's illumination of the sense of responsibility that is mobilized in silent yielding. These silences are both destructive and reconstructive; the intention is to kill whiteness; a call for whites who have previously considered themselves to be whites to destroy their white existences. This, in turn, can lead to engagement and even agonistic contestation on terms hardly imaginable under racialized regimes. Silence can work to disengage a way of living together, including a series of relationships built upon a given truth regime. Yet, this same silence can work equally hard at making space for building new, more thoroughly just, relationships and responsibilities. Such a silence can therefore involve mending, a bringing together that helps establish more democratic communities. Silence is an important democratic alternative for those in positions of privilege who desire to construct more equal political relationships. Silence can become a way to listen, better understand and dismantle such privilege.

\section{References}

Bell, D. (1992) Faces at the Bottom of the Well. New York: BasicBooks.

Block de Behar, L. (1995) A Rhetoric of Silence and Other Selected Writings. New York: Mouton de Gruyter. 
Brown, W. (2005) Edgework: Critical Essays on Knowledge and Politics. Princeton, NJ: Princeton University Press.

Cheung, K.-K. (1993) Articulate Silences. Ithaca, NY: Cornell University Press.

Cheung, K.-K. (1994) Attentive silence in joy Kogawa's Obasan. In: E. Hedge and S.F. Fishkin (eds.) Listening to Silences. New York: Oxford University Press.

Cover, R. (1995) Violence and the word. In: M. Minow, M. Ryan and A. Sarat (eds.) Narrative, Violence, and the Law. Ann Arbor, MI: The University of Michigan Press.

Dauenhauer, B. (1980) Silence: The Phenomenon and Its Ontological Significance. Bloomington, IN: Indiana University Press.

Delgado, R. and Stefancic, J. (2001) Critical Race Theory: An Introduction. New York: New York University Press.

Duncan, P. (2004) Tell This Silence. Iowa City, IA: University of Iowa Press.

Ferguson, K. (2003) Silence: A politics. Contemporary Political Theory 2: 49-65.

Gay, Lesbian and Straight Education Network Day of silence, http://www.dayofsilence.org, accessed 1 March 2006.

Haraway, D.J. (1997) ModestWitness@Second Millennium.FemaleMan_Meets OncoMouse. New York: Routledge.

Hooks, B. (1989) Talking Back: Thinking Feminist, Thinking Black. Boston, MA: South End Press.

Jaworski, A. (1993) The Power of Silence. Newbury Park, CA: Sage Publications.

Lopez, I.H. (1996) White By Law. New York: New York University Press.

MacKinnon, C. (1989) Toward a Feminist Theory of the State. Cambridge: Harvard University Press.

McIntosh, P. (2004) White privilege: Unpacking the invisible backpack. In: M. Anderson and P.H. Collins (eds.) Race, Class, and Gender, 5th edn. Belmont, CA: Wadsworth.

Mills, C. (1997) The Racial Contract. Ithaca, NY: Cornell University Press.

Minh-ha, T.T. (1990) Not you/like you: Post-colonial women and interlocking questions of identity and difference. In: G. Anzaldua (ed.) Making Face, Making Soul. San Francisco, CA: Aunt Lute Books.

Pateman, C. (1988) The Sexual Contract. Stanford, CA: Stanford University Press.

Saville-Toike, M. (1985) The place of silence in an integrated theory of communication. In: D. Tannen and M. Saville-Troike (eds.) Perspectives on Silence. Norwood, MA: Ablex Publishing Corporation. 